\title{
Palestra proferida na abertura do \\ XI SEMINÁRIO NACIONAL DE BIBLIOTECAS UNIVERSITÁRIAS: A BIBLIOTECA UNIVERSITÁRIA DO SÉCULO XXI, 24 a 28 de abril de 2000
}

\author{
Sigrid Karin Weiss Dutra - sigrid@bu.ufsc.br \\ Presidente do Evento e \\ Diretora da Biblioteca Universitária \\ Universidade Federal de Santa Catarina
}

Senhoras e Senhores

Inicialmente, desejamos boas vindas aos participantes deste grande evento, às autoridades que nos prestigiam com suas presenças, aos organismos que nos auxiliaram na organização deste Seminário.

O apoio da Universidade Federal de Santa Catarina e a perfeita sintonia com o Departamento de Ciência da Informação - CIN - foram imprescindíveis ao sucesso que se prenuncia neste início do evento.

Os resultados de treze meses de trabalho intenso, com certeza, refletirão a nossa preocupação de estruturar o SNBU2000 de forma a permitir que as Bibliotecas Universitárias encerrem este século com uma nova e avançada visão do futuro.

Santa Catarina é o que os visitantes já puderam observar. Um Estado hospitaleiro, singular na beleza, empreendedor nas atividades econômicas e se constitui no segundo maior pólo de produção de software do País, graças, principalmente, à grande contribuição da nossa Universidade Federal.

Sejam bem-vindos a este Estado simplesmente maravilhoso.

Senhoras e Senhores,

O décimo primeiro Seminário Nacional de Bibliotecas Universitárias, o último deste século, lança-nos a um grande desafio. Se em menos de cinco anos a Internet já acumula cinco bilhões de palavras e a cada mês somos surpreendidos por novas alternativas tecnológicas e por avançados programas que cada vez mais simplificam o acesso à informação, como estruturar a nossa casa, a Biblioteca Universitária, para não correr o risco de defasagem eminente?

Se a dez anos atrás os sistemas de informação permitiam-nos a tranqüilidade de organizar e disponibilizar as informações em um processo sereno, até porque as publicações 
em geral obedeciam ao ritual da tecnologia dos impressos, hoje estamos em uma verdadeira batalha contra o cronômetro.

Não se trata somente da guerra tecnológica, da capacitação permanente dos recursos humanos, da virtualização dos meios ou da obtenção de recursos financeiros para acompanhar a evolução. O desafio é a gestão da qualidade que coloca a Biblioteca em tempo real com a velocidade da informação.

A Biblioteca não é apenas um processo de armazenamento de informações e conhecimento. A sua sobrevivência em qualidade exige discernimento entre dados, informações e conhecimento, sob pena de não estar contribuindo mais para a organização da própria Universidade.

A Biblioteca deixou de ser apenas um acervo de informações da Universidade, para se transformar em uma peça valiosa no planejamento das mudanças da própria universidade. Ou seja, a Universidade moderna, que tem a informação como a sua principal matéria-prima, com certeza, já tem a consciência de que a Biblioteca precisa destacar-se como a prioridade em suas estratégias de investimentos.

Vivenciamos a conflagração da mudança de uma cultura de conhecimento provocada pela revolução tecnológica. Se da revolução industrial ao final deste século o desenvolvimento tecnológico foi gradativo, a ponto de o telefone necessitar quase de um século para atingir setenta milhões de usuários, hoje vivemos a ansiedade das transformações quase que em tempo real. Vivemos a perplexidade dos ajustes, mergulhados no corre-corre das inovações. Todos querem estar na vanguarda. Mas que vanguarda? A da inovação? O que significa inovar às vésperas de um novo século que promete nos liberar de instrumentos, máquinas, etc. para através apenas de um chipp termos acesso a todas as informações?

Se seremos dispensados do uso de máquinas, computadores, leituras visuais para obter informações, o que será então da Biblioteca? A resposta imediata seria a virtualização dos meios. Mas isso não é o suficiente. A transformação da Biblioteca no começo do próximo século deverá - isto sim - ser radical na sua própria missão. Os grandes acervos continuarão sendo referências históricas e patrimoniais, enquanto que a Biblioteca do futuro talvez não precise mais deflagrar-se com problemas de espaço, considerando que a disseminação e diluição da informação tornarão indispensável a simplificação dos processos através da segmentação cada vez maior do conhecimento e das informações.

Já na primeira década deste século, a roleta e os detectores de roubo estarão ultrapassados; os recursos humanos serão cada vez mais especializados; o estudante diante de 
um computador em qualquer lugar, talvez com menor freqüência na sala de aula, estará integrado à Biblioteca.

Estas mudanças são para amanhã. E a Universidade que não estiver preocupada com a velocidade destas mudanças com certeza sofrerá uma queda brusca na qualidade.

A Biblioteca como epicentro das transformações acadêmicas já sugere que a produção científica comece a abandonar paradigmas que ainda alicerçam as gorduras da informação em boa parte das publicações, transformando-as em lições objetivas, isentas de rodeios, sem comprometer a substância.

Estamos às vésperas da inauguração da Internet 2 em nossa Universidade, com 30 megabits ligando-nos à São Paulo. É difícil de imaginar a estrutura de comunicação de que disporemos nos próximos cinco anos, a velocidades imprevisíveis. E isso resume o nosso grande desafio: velocidade em tudo, no aprender, no fazer, no mudar, no modernizar-se. A realidade exibe uma metamorfose que sacode todas as áreas do conhecimento. E na reordenação dos processos a Biblioteca precisa ampliar seu leque de participação e de contribuição na organização e sistematização das informações.

Acreditamos, Senhores e Senhoras, que este Seminário será a grande sacudida neste final de século, acordando-nos para a realidade, indispondo-nos contra o comodismo, o egocentrismo e a paciência. Precisamos nos tornar cada vez mais irrequietos para superar os entraves das mudanças e os riscos do obsoletismo.

A velocidade é bem mais que a superação de distâncias.

A velocidade é hoje uma luta de sobrevivência contra o tempo que já é real.

Obrigada! 